\author{
VITALIY BILETSKY, \\ Vasyl' Stus Donetsk National University (Vinnytsia, Ukraine) \\ e-mail: biletsk750@gmail.com, ORCID0000-0003-2818-131X
}

\title{
DISCOURSE OF MANIPULATION OF CONSCIOUSNESS IN LITERARY WORKS OF A. HUXLEY AND THE STRUGATSKY BROTHERS. ANALOGIES WITH MODERNITY
}

\begin{abstract}
In the article the author shows how literary works of the utopian and dystopian genre can serve as a source of scientific, in particular, socio-philosophical analysis of social phenomena. Interested in the phenomenon of manipulation of the mass consciousness, the author searches among writers for those who depict it with vivid artistic imagery. Aldous Huxley, Arkady and Boris Strugatsky and their corresponding works: "Brave New World", "The Inhabited Island", "Noon: 22nd Century" etc. are considered. These authors carefully and comprehensively build a dynamic picture of public relations and the state of public institutions, both during public calm and in the situation of the invasive war. Through the use of a number of scientific methods, it was discovered that the writers showed manipulation of the mass consciousness quite mature in terms of sociology, social philosophy, religious studies and social psychology. Their fundamental vision of instrumental influence on the masses of people is identical with the scientific one. The same applies to the approach to demonstrating modifications of the institute of public morality, religion, pedagogy and education for influencing the population. The author concludes particularly about the similarity of the modern manipulative political influence on the citizens of Ukraine to the influence existing in the Aldous Huxley's world of total consumption, the degradation of the Christian morality. In turn, the militaristic treatment of the population, shown by the Strugatsky brothers, is identical to the propaganda that is taking place today within the Russian Federation. It is emphasized that the particular usefulness of analyzing literary works of this type is in addition to a purely rational picture, which is given by the scientific knowledge, and acquaintance with these works may initiate relevant scientific intelligence to trace parallels and analogies.
\end{abstract}

Key words: manipulation of consciousness; "mass-man"; "T Era"; "The Final Circle of Paradise"; "Noon"; socio-philosophical views; dystopia; personality degradation; belief; mass humility.

\section{Introduction}

A series of our recent works was devoted to the phenomenon of manipulation of the mass consciousness, which has currently taken place both in our and in the neighboring aggressor country (Struhatskyi, 2016a,b; Biletskyi, 2017; 2018; $2019 a b$ ). In particular, it was found that artificial gradual instrumental latent influence on the emotional-cognitive components of the psyche of the "mass-man" facilitates the perception and internalization of anti-state discourses, leads to a loyal attitude to the aggressor before and during the period of occupation, induces to schismogenetic discourses.

Purposeful clouding of critical thinking, instrumental potentiation of affect to the masses was also revealed during electoral activity at last year's elections. It has led to the fact that, due to political myth-making, the place of President of Ukraine is currently occupied by a person with no previous experience of relevant work - with relevant consequences arising from this fact.

In general, our analytics has shown that the reduction of the population to the vulgar state of the Ortega y Gasset's "mass-man" and the arbitrary manipulation of man's consciousness are a pronounced vector of the expansionist foreign policy of the neighboring state, as well as of the domestic policy, since in the latter case it allows to keep the masses in intellectually drowsy and nearly euphoric state. At the same time, almost anyone can be the object of euphoric exaltation, as the election of the President of Ukraine has shown. This person is simply set by manipulators, and the masses uncritically consume the instrumentally created and broadcast mythologems.

Exploring presented problematic issues, we relied on a professional social, philosophical and other related authors (Dodonov (ed.) and others, 2017). In particular, corresponding ideas of E. Fromm, H. Spencer, J. Ortega y Gasset, S. Moscovici, G. Le Bon, C. Lévi-Strauss, M. Eliade, C.G. Jung, M. Mark, K. Pearson, J. Campbell, Ph. Zimbardo, M. Leippe, E. Cassirer, H. Kuromiya were studied. Positions of national and Russian-speaking scholars of the past and present, such as V. Propp, S. Kara-Murza, R. Dodonov, V. Skvorets, I. Pasko, J. Pasko, H. Korzhova were also analyzed. A rich amount of facts about cases of mass consciousness manipulation reported in the mass media was also considered.

Along with this, the study of socio-philosophical, sociopsychological, politological works often appealed to publicistic works and prompted us to use relevant concepts, such as "Goebbels's propaganda", "zombieing" etc. We believe that it is necessary because the social sciences create only a particularly rational image of manipulation of the mass consciousness. Serious analytical, minimally emotional journalism, in fact, is parascientific and adds 
imagery and facts to the picture of humanitarian knowledge. It adds its piece of information to the general understanding of the process. However, this fragment is not sufficient for complete reflection.

As is known, manipulation of the mass consciousness, ways of controlling the crowd are vividly depicted in a number of literary works, prominent authors of which, long before the spread of the total practice of such suggestion and rooting of political myths, nearly prophetically enlightened both manipulative practices and their consequences.

But is it appropriate to consider a literary work as a source of philosophical deduction?

The author of the article thinks that it is entirely appropriate because the philosophical works themselves are often presented to the reader as socially oriented fantasy or futuristic literature. This is evident from the examples of Plato, Th. More, T. Campanella, J. Swift, H. Skovoroda, in whose known works they worked in the theory of social modeling in the form of, in fact, fiction aimed at socio-political, technological or psychological-existential horizons.

In the nineteenth and twentieth centuries, R. Heinlein, I. Asimov, A. Huxley, G. Orwell, R. Bradbury, E. Burgess, S. Lem, Mikhail Bulgakov, Yevgeny Zamyatin, Tatyana Tolstaya, Arkady and Boris Strugatsky, Ivan Yefremov and other writers did the same.

Sadly, but the works of the above-mentioned writers are scarcely analyzed by professional philosophers and are not traditionally qualified as philosophical. This occurs because of the excessive and unjustified narrowness of the scientific view or because of a kind of conservative mannerism that artificially separates "classical philosophers" from "non-classical" ones.

The author of this work, of course, does not share this point of view and regards as philosophers a large number of non-academic artists, including the above-mentioned writers, a number of cinematographers, theatrical figures, masters of figurative arts, who encourage theorizing and philosophical reflection on the reality.

Therefore, our future scientific research is lying namely in the area of search and clear articulation of sociophilosophical accents in the object of study which is presented by a number of works by some of the mentioned literary authors. In context of the continuation of previous studies, we are interested first of all in the emphasis on manipulation of the mass consciousness, its consequences etc.

Specificity of this type of works inevitably requires concretizing the subject field, and in this article we intend to study the work "Brave New World" (Huxley, 2014), by Aldous Huxley, as well as a number of works by Arkady and Boris Strugatsky, such as "The Inhabited Island", "Noon: 22nd Century", "The Final Circle of Paradise" (Strugatsky Arkady and Boris, 2016a,b; 2018). The choice is explained by the fact that the accents that we are interested in are presented with obvious expressiveness in these works.

\section{Methods}

The methods used by the author in writing this article include, in addition to the scientific analysis of the texts, a comparative approach to comparing works of art according to the purpose. After such a comparison and separation of relevant information, we intend to use the method of moving from abstract to concrete and to find analogies between the literary figures' relevant views on socio-political processes and objective reality. An interdisciplinary app- roach is also involved, because manipulation of the mass consciousness can only be comprehensively analyzed with the involvement of social philosophy, sociology, spheres of psychological knowledge, as well as religious studies.

\section{Results and Discussion}

Aldous Leonard Huxley portrays a society in a state of social peace in his dystopia. This calm, conformity, political loyalty to power and virtually total life satisfaction are achieved by nothing but the manipulation of the mass consciousness - the hidden instrumental influence on it.

The vectors of such influence are depicted throughout the first chapters of the novel and, in particular, proclaimed by the Resident Controller for Western Europe Mustapha Mond. The latter constantly emphasizes in his thesis that a society, a fetish of which is a totally rooted idea of consumption of economic benefits and belonging of citizens to each other, is an ideal and stable social organism.

Analyzing the novel, we can identify and articulate a list of institutional resources and principles by which such a society was built and truly maintained in a state of stability:

- First of all, the author skillfully from the point of view of sociology uses the recalling that the World State began to emerge in the postwar period - after the so-called "Nine Years' War" mentioned in the novel. It is difficult to disagree that this is a good explanation of how a new society emerged, was initiated, and the old social order had fallen into oblivion. Indeed, during this period (postwar), the anonymization of society, disorder, state of ruin, despair, negativism, precarious moral, law and religious standards are extremely strong. All this is s perfect basis for revolutionary transformations - namely at this time, mental discourses, moods of the population can be skillfully modified and quickly retargeted at the right vector;

- At the beginning of the social revolution, that led to the emergence of the World State at the end of the twentieth the beginning of the twenty-first century, there was a terror in the intellectual social groups through mass executions that were mentioned under the name "British Museum Massacre";

- The "campaign against the Past" also included the destruction of historical monuments, closure of museums, removal and destruction of books containing history data etc. Thus, the ground for erasing the public memory and careful and quick (for decades) replacing it by the discourses necessary to control the "brave new world" was created;

- At the same time, there was an aggressive liquidation of traditional religions. In Nietzschean way, Huxley through his characters criticizes Christianity, in particular, radical differences between its ideological precepts and cynical practice of the real life and the behavior of believers;

- The purposeful formation of a new artificial belief system - neoreligion. Huxley skillfully depicts its necessary components: ideological base, spiritual actions and religious organization. The ideology of this newly created and powerful social regulator is generally the following. At the beginning of the "Ford's era", the corresponding sacralized embodiment of the single right, standard revelation - Ford or, as he called himself, Freud (in the religion these persons were merged) reflected on the causes of human unhappiness. He concluded that the causes were deep emotions and everything that causes them - family relations, fatherhood, motherhood, monogamous marriage, enmity related to both deficit of consumption products ("under-consumption") and endogenous individual psychological causes. Numerous traditional arts are also 
deleterious. All this, as well as deep feelings, was tabooed and called sinful, worthy of disgrace, disgust, rejection and eradication. In contrast, it was proclaimed that a person should focus on public rather than personal goals and objects, and the person would be happy if he or she easily consumes and produces a socially useful product himself. For the emotional and sensitive person of the new age, the world should be light and easy, since the institution of family as such is abolished, no place remains for romance because everyone must be available to everyone - everyone can and must be actively "tasted" - in leisure and sexually-erotic way. By mutual desire, everyone belongs to everyone. According to such a religious idea, the religious community is whole society except for single or small groups of fringe people who are affected by sanctions or live in reservations. Religious activity include created prayers, recitative liturgical poems presented in the novel, appeals to Ford like "Oh, Ford!" and emotional exaltation under the influence of "synthetic" music, smells and consecrated easily accessible narcotic substance soma with twelve close acquaintances and friends. The drug (soma) is proclaimed harmless helpful and useful for achieving a relaxed (etalon) emotional state, a sense of ease of life, euphoria, shallow emotions. These religious principles have become a cornerstone of the "T Era". And the corresponding letter $\mathrm{T}$, which derived from the name of Henry Ford's "T-Model" car, was sacralized as a sign - it replaced the Christian Cross;

- In addition to the ideological-religious propaganda and already mentioned continuously compulsory used drug, the world society at peace and stability is reproduced and maintained by purely technological means that are reduced to eugenic and enthi-eugenic procedures with human embryos received through artificial mass (conveyorfactory) fertilization. Thus, the state apparatus of public administration forms citizens in the network of incubators in advance "for themselves" with the help of the technological system - "bokanovskification". The eugenic and degradation-regressive physiological-morphological procedures divide society into typical classes according to the criterion of the development of thinking and the perfection of physical appearance since the embryonic phase. The citizens of "Alpha" and "Beta" classes, capable of self-awareness and thinking, later occupy the relevant creative and intellectual functions of society, and the rest of people, quite ugly appearance, are engage in physical service non-prestigious work. But they are also quite satisfied with their lives - they are inculcated with the relevant ideas about caste pride, necessity, importance of their work, drug-soma is also available to them etc.;

- Specific total state pedagogy (educational, hypnopædic, sexual-educational training) and powerful influence of the institute of a kind of social morality are involved in forming and maintenance of people's state of mass satisfaction and humility from early childhood. "You rule with the brains and the buttocks, never with the fists" such phrase is proclaimed by the power holder in Chapter 3 of the novel in an instructive conversation with a young generation of "Alpha" caste people. New morality and pedagogy, acting symbiotically with neoreligion-Fordianism, cultivates norms and taboos in early childhood, enriches them with "neo-Pavlovian reflex formation", enroots aspects of caste consciousness related to selfidentification and a clear hierarchy of caste subordination "till at last the child's mind is these suggestions, and the sum of the suggestions is the child's mind. And not the child's mind only. The adult's mind too - all his life long.
The mind that judges and desires and decides - made up of these suggestions. But all these suggestions are our suggestions! ... Suggestions from the State". Hypnopædic pedagogy and social morality also emphasize the normality of total and dynamic consumption of goods and services (sports, media, recreational, "synthetic" art, etc.), sexual freedom and the ease of personal relationships. It should be noted that words "mother", "father" become rude expressions. Therefore, T Era institutions stigmatize deep emotions, feelings as shameful and harmful - they are strictly tabooed on the subconscious level - as well as consideration of individual originality and uniqueness. Easy life, everyday use of sacralized soma, using each other as objects, fetish-like active public-demonstrative consumption of material and "spiritual" goods, demonstratively relaxed easy emotional state, feeling of pleasure, optimism, sense of a group to which all belong - are social duties of each person. "Community, identity, stability" is the main slogan and principle of the World State;

- The state propaganda institute also contributes to the stabilization of the "brave new world" society. In corresponding institutions, the technologists who form senses dynamically produce slogans, mottos, iconographic, cinematic, agitational and propaganda products, which later are broadcast by pedagogy, hypnopædic education, the press and arts. These slogans refer to consumer goods, a fashion for which is rapid, caste relations and self-awareness, religious precepts, usefulness of the soma and the entertainment industry. "Words can be like $X$-rays, if you use them properly-they'll go through anything. You read and you're pierced" - these are words of one of the characters in the novel, who is an appropriate technologist. Here are some of these slogans: "What you need is a gramme of soma", "a gramme is better than a damn", "passion and neurasthenia mean instability", "everyone belongs to everyone else", "ending is better than mending", "I'm so glad I'm a Beta", "cleanliness is next to fordliness".

We are interested in the lyrical-dramatic history not so much as in the skillfully written context of the complex of social regulators, their means and social consequences. However, it also demonstrates the impossibility of adaptation into the "brave new world" of the T Era of a person with "outdated", contrastively different (close to Christian) moral attitudes. Instead of the expected and desired deep love, society gives only a surrogate - a shameless sexual freedom, instead of creative activity it gives the concept of hedonistic consumption, sameness, averaging of the individual and permissiveness.

Soviet fiction classics Arkady and Boris Strugatsky also powerfully analyzed the social context of personality development in the abstract future. This is obvious, for example, when reading the chain of stories and novels "Noon: 22nd Century", "The Inhabited Island", "Hard to Be a God", "The Doomed City", "The Final Circle of Paradise", plots of which are often connected.

Strugatsky's society of a stable social peace, thoroughly shown in "Noon", in contrast to Huxley's one stands on the foundations of respect for individual, comprehensive, relaxed and arbitrary personality development, both emotionally-psychologically and scientifically-professionally.

The moral norms of a planetary or even pangalactic society are not too different from those which are considered habitual, close to Christian ones by a reader. How are they learned? There are monogamous families in which children are born in the usual way. However, from 
an early age, society encourages their upbringing by professionals in institutions that are comfortable boarding schools. Parental visits or refusing to send their child to such boarding school is not prohibited, but it is a common practice to refer children to specialists. The child is being raised in a group of peers - a teaching and learning group. Each of these groups has a Tutor and a Teacher. The first of them pays particular attention to the individual psychological and moral progress of each student. Being a skilled psychologist with a proven reputation and relevant experience, he cultivates and encourages the development of self-awareness, willpower, flexible thinking, autonomous moral readiness. It is a highly respected profession, just like the Teacher, a number of whom are involved in the inoculation of particular scientific disciplines.

After leaving school, a person is endowed with moral imperatives close to Kantian. In other words, society allows and encourages any further self-development - from the socially useful to the individually directed providing in no way to think of social harm and to be able to be an autonomous moral being. Accordingly, society by state institutions, such as the World Council, and more by public morality strictly forbids the restriction of the development of the individual and any forms of violence which make it impossible.

Accordingly, endowed with such a desire for selfdevelopment and self-realization, self-control, a young man learns further, finds a profession, trains, gradually becomes a master, can change the profession or devote himself to, for example, art, or become a traveler, or plunge into entertainment. The latter, of course, is not related to Huxley's vulgar hedonism, it is connected only with activities - sports and leisure, visual arts, ethnographic exploration, amateur archeology etc. Sexual relationship with people preserves privacy, discreetness, subtle eroticism and equal rights.

Therefore, the society of Strugatsky's future honors the family, hierarchizes people by age and social importance, nurtures civic responsibility, creative work when cultivating the inequality, uniqueness and individuality of every person who lives plunging into personal and social relationships - often difficult and tragic. Again, a cornerstone, a safety lock that does not allow anyone to turn into a shameful savage, villain, evil gossiper, hypocrite, etc., is an autonomous morality that has been cultivated from childhood and adolescence. If a person loses it and it is found by others, then, regardless of social status and position, he is socially shamed, disgraced as a degraded, backward person with distorted morality, close to the animal. Such case, for example, is described in the novel "Space Apprentice" (incident on the Dione).

However, Strugatsky also noted that the transition to the society of the "Noon" will not be simultaneous and smooth - material well-being and prosperity in no way entails spiritual development and, in the absence of stimulating and educational influence, will lead to spiritual degradation.

The novel "The Final Circle of Paradise" shows a society similar to Huxley's one. It is a bourgeois society where a citizen can choose a variety of ways to cherish hedonistic appetences from aggressive-extreme to culinary by joining corresponding civil society organizations ("Fishermen", "Intels", "Firsts", "Patrons", etc.). Television also broadcasts works of mass culture. Drug-like brain stimulation, which is fashionable, group and public, is legalized (a neurostimulator- dream generator, "Shivers"). In these conditions of the permissiveness of pleasures people reach a state of satiety, so to say "cloyingly", and they seek to find a new, most effective way to take pleasure. Such a drug ("slug") is found, the protagonist of the novel - an undercover agent of the World Council is combating its proliferation and emphasizes the threat of rapid world wide spiritual crisis, destruction and degradation of any personality, unless the social institutions that have to encourage people to develop will, morality, creativity, thinking and cultural-aesthetic wealth start working.

A society in a state of permanent war - not earthmen, but genetically identical people is depicted in detail in the novel "Prisoners of Power" ("The Inhabited Island"). Here the context of manipulation the of mass consciousness with the help of technical means (different types of radiation) is shown most clearly. Society as a whole and virtually any individual of it is easily manipulated and directed to any idea or object of belief. The military state regularly (at least twice a day) exposes the population to radio waves that cause strong faith together with emotional exaltation. Constantly covered by the institute of state propaganda, people in a process and after such treatment lose their critical thinking, feel the godlikeness of power ("Unknown Fathers"), their invisible presence, euphoria and emotional passion, that is, feelings identical with religious reverence. Thus, social apathy, negativity, depressive states, which are inevitable during economic degradation, inflation, environmental degradation, poverty, epidemics, high mortality that accompany a country warring by nuclear weapons are easily overcome. At the same time, it is easy to cause other people's feelings - at the choice of manipulators - for example, to spread totally depression, sadness or fierce compulsive anger. With the help of propaganda corresponding feelings can be channeled to a particular object - hostile country or individuals of native country who are unaffected by manipulation of consciousness and must be destroyed - they are called "degens".

Thus, the society is thus truly stabilized, and the revolutionary situation is easily overcome by suggesting appropriate political ideas and repressive control over immune individuals ("degens") by the punitive and security structures - the army, the guards, the prosecutor's office, the judicature. There is no need for Huxley's drugs, hypnopædia or the inculcation of social reflexes from childhood with the use of "neo-Pavlovian" (electroshock) methods - manipulation of the mass consciousness is not indirect, it occurs directly - so to say, on "naked" brain.

That is a rhetorical question if, reading the works of the authors cited, analogies with the scientifically researched picture of the technology of manipulation of consciousness can be seen. It is obvious. Writers, classics of social philosophy and systematizers of their ideas, such as S. KaraMurza (2005), speak of two principles that the manipulator seeks to adhere - to influence the thinking and emotional sphere of the masses.

The analogies with the social reality of the recent past are clear. In early stages of the formation of the USSR, the terror on intellectuals and the substitution of Christianity for political neoreligion with appropriate idols and rituals, the substitution of history, political myth-making which a person had been immersed in since childhood, were observed.

The similarity of modern reality to Huxley's one is also doubtless. In order to maintain public calm, political forces, implicitly influencing the population, particularly in Ukraine, keep it in a state of typically Ortega y Gasset's masses in ways similar to those described in "Brave New World" only ways of influence differ. Huxley wrote about the hypnopædia, the training of infants with electric shock, work 
with human embryos and narcotic soma, Strugatsky - about radiation.

In reality, the manipulator uses the media, easily suggesting appropriate mythologems without the use of fantastic technologies. At the same time, in the current reality, it can be easily observed how ideas of consumption of goods, services, entertainment, easy life saturated with euphoria and carefreeness are being actively implemented. This flow is a familiar information environment for children and adolescents. Currently there is no state propaganda of healthy lifestyles, sports, family values, traditional forms of art, ethics, reading culture, social responsibility in Ukraine.

As a result, we have the mass saturated with the desire to dawdle, drink alcohol while maintaining a feeling of serenity. The shame is also partly reduced. The demonstration of body parts, irresponsible attitude to sexual and erotic contacts, psychological unwillingness to be a dad, mother, wife, husband - all this is quite obvious. Neither the state, nor the relevant national institutions of public morality and education do not set for interest in something creative and intellectual. There is no advocacy for these values and the relevant needs. Those wishing to oppose such a categorical position may recall at first what the celebration of, for example, the anniversary of a faculty, Students Day looks like - can learning youth show a lot of cultural creativity, or they simply move their bodies rhythmically with sound of drums? How many students tend to copy other people's texts when writing essays, thesis or graduation works? Are such disciplines as logic and ethics compulsory taught in Ukraine today, and what degradation have the actions of higher education reformers led to? It can also be traced how a significant part of the population behaves publicly, whether there are many swear words in speech, whether acquaintances are members of a local library, what the faces of ordinary people or even of reputable new-fashioned politicians are, whether they can give a note-free speech, whether a modern citizen demonstrates a lot of intellectual erudition and if his or her interest are confined to alcohol, sexual relations and his or her own empty bombast?

In other words, the Huxley's society of carefree consumption or society of "predatory things" of the Strugatsky's "The Final Circle of Paradise" - the society of an intellectual and creative inability is a very real and familiar environment. An additional analogy relates to soma, since the trend of legalization of some drugs is also a moment of current reality.

We see analogies with the society during the invasive war in reality on the example of the Russian Federation. In the works (Biletskyi, 2018; Dodonov (ed.) and others, 2017) ways of the influence on thinking and emotional sphere of Russians and citizens of Ukraine before the occupation and at other stages of the so-called "hybrid war" was explored. The Strugatsky brothers vividly showed a picture of the identical processes of clouding of critical thinking and increasing affect, set by the manipulator of emotions. That is, here we see the convergence of ideas. The difference between the instantaneous impact of zombieing radiation and the somewhat delayed (within months) impact of media and state propaganda is not significant.

Summing up the above, we can draw the following conclusions.

1. In analyzed works the considered classics of literature acted, so to speak, unanimously with scholars who researched political influence on the masses.

2. The writers' picture of the process of manipulation of the mass consciousness, if we do not take into account the purely fantastic or currently forbidden (eugenics) technologies, is reduced to two processes that are quite identical with those found by scientists. The first concerns the influence on thinking, and the second concerns the influence on the emotional sphere. At the same time, both representatives of science and writers believe that the main purpose of manipulators is to reduce the psychological state of the masses to belief in a particular object. It is rightly stated that all mature processes of logical thinking are thoroughly and comprehensively degraded, it becomes uncritical, incoherent, a person does not accept or ignores uncomfortable arguments, loses long-term memory - this has been analyzed in detail by us and colleagues earlier.

3 . The analogies with current social reality are also quite obvious. The appearance of the USSR appeals to the Huxley's picture. The current political trend in Ukraine clearly tends to turn the people into Ortega y Gasset's masses, a crowd whose fetish is not total creativity but total consumerism. The socio-psychological characteristic of the crowd combines the lack of creative intentions, the attraction to sensually exhausted mass culture which potentiates almost animal attraction, spiritual immaturity, weakness of autonomous will and morality. Namely these features, that we can see in reality, are given by Huxley and representatives of humanitarian knowledge. It is not difficult to manage the masses with the help of manipulative media techniques, which is happening now.

4. In the course of invasive-imperial intentions of the political leadership, hidden influence is also a basic tool for influence on one's own citizens. By activating the belief in impeccability, sacredness, holiness of a particular object, such as a leader, nationality, country, language, lifestyle, etc., and instrumentally raising hatred of a particular enemy, it is possible to turn the war into a social reflex of the population - its modus vivendi; that is what happened with a real aggressor state, but was previously prophesied by Strugatsky.

5. Both writers and scholars are unanimous in the view that state propaganda symbiotically complements the manipulation of consciousness. It also strengthens faith, clouds thinking and evokes set emotions. We know what role such propaganda played in the USSR, in Nazi Germany, and what role it plays now in Russia. Regarding Ukraine, it (propaganda) is activated only concerning political figures. The state is not interested in spreading other ideas in the public consciousness, for example, concerning traditional values (family, marriage, motherhood, fatherhood, intelligence, ethics). Thus, the state of society of our state tends to the "T Era" world rather than to the "Noon" world.

6 . The literary works of the analyzed authors do not contradict, but do complement the scientific vision of social processes, adding to the philosophical, sociological, psychological reflection imagery, a sense of involvement in the event, and a live presence. However, reading such works leads the scientist to a desire to dissect the relevant aspect of social existence scientifically, making rationally reasonable predictions - the works also act as a kind of source base.

\section{REFERENCES}

Biletskyi, Vitaliy (2017). Moralno-intelektualne vidrodzhennya vitchyznyanoho suspilstva - ? Proceedings of the All-Ukrainian Scientific and Practical Conference with International Participation on the 80th Anniversary of Donetsk University Establishment (Vinnitsa, April 4-5, 2017). Vinnitsa: FF Korzun, pp. 202 - 206. (In Ukrainian) 
Biletskyi, Vitaliy (2018). Manipulyatyvni praktyky na tli hibrydnoyi viyny. Kyiv: Khalikov Publisher, 166 p. (In Ukrainian)

Biletskyi, Vitaliy (2019). Politychnyy vybir yak indykator mentalnoyi zrilosti suspilstva. Proceedings of the Ukrainian Scientific and Practical Conference "Philosophical Reflections of Contemporary Worldview Discourses" April 19-20, 2019. Vinnytsia: Korzun Publisher: 33-37 (In Ukrainian)

Biletskyi, Vitaliy (2019). Political agitation and state of mental maturity of the domestic society. Skhid. 3 (161): 53-56. DOI: http:/ /dx.doi.org/10.21847/1728-9343.2019.3(161).171721

Dodonov (ed.) and others. (2017). Hybrid war: in verbo et in praxi. Vinnytsia: Nilan Ltd, 412 p. (In Ukrainian)

Huxley, Aldous (2014). O divnyy novyy mir [Oh brave new world]. Moscow: ACT, 288 p. (In Russian)

Kara-Murza, S. (2005). Manipulyatsiya soznaniyem. Moscow: Eksmo, 832 p. (In Russian)

Strugatsky, Arkady and Strugatsky, Boris (2016). Khishchnyye veshchi veka [Predatory things of the century]. Moscow: ACT, 256 p. (In Russian)

Strugatsky, Arkady and Strugatsky, Boris (2016). Polden, XXII vek [Noon, XXIl century]. Moscow: AST Publishing House, 352 p. (In Russian)

Strugatsky, Arkady and Strugatsky, Boris (2018). Obitayemyy ostrov [Inhabited island]. Moscow: ACT, Neoclassic, 480 p. (In Russian)

Struhatskyi, V. (2016). Aggressive technologic impact on mass consciousness against the background of East Ukrainian conflict. Setting the stage and first myths. Skhid, 3(143). DOI: http:// dx.doi.org/10.21847/1728-9343.2016.3(143).74859 (In Ukrainian)

Struhatskyi, V. (2016). Aggressive technologic influence on mass conscience against the background of the East Ukrainian conflict. Mythology of the military phase. Skhid, 4(144), 92-100. DOI: http://dx.doi.org/10.21847/1728-9343.2016.4(144).78100 (In Ukrainian)

\section{LIST OF REFERENCES LINKS}

Білецький В. Агресорний технологічний вплив на масову свідомість на тлі східноукраїнського конфрлікту. Підготовка ґрунту і перші міфи. Схід. 2016. № 3 (143). С. 93-100.

Білецький В. Агресорний технологічний вплив на масову свідомість на тлі східноукраїнського конфрлікту. Міфологія мілітарної фази. Схід. 2016. № 4 (144). С. 92-100.

Білецький В. В. Політичний вибір як індикатор ментальної зрілості суспільства. Матеріали Всеукраӥнської науково-практичної конфреренції "Філософрські рефрлексії сучасних світоглядних дискурсів" 19-20 квітня 2019 року. Вінниця: ФОП Корзун, 2019. С. 33-37.

Білецький Віталій. Маніпулятивні практики на тлі гібридної війни. (Монографрія). Київ: ФОП Халіков Р.Х., 2018. 166 с.

Білецький Віталій. Морально-інтелектуальне відродження вітчизняного суспільства - ? Матеріали Всеукраїнської науково-практичної конференції з міжнародною участю, присвяченої 80-річчю заснування Донецького університету (м. Вінниця, 4-5 квітня 2017 р.). Вінниця: ФОП Корзун, 2017. C. 202-206.

Гібридна війна: in verbo et in praxi: монографія / за заг. ред. профр. Р. О. Додонова. Вінниця: ТОВ Нілан- ЛТД, 2017. 412 с.

Кара-Мурза С. Манипуляция сознанием. Москва: Эксмо, 2005. 832 c.

Стругацкий Аркадий, Стругацкий Борис. Обитаемый остров. Москва: АСТ, Neoclassic, 2018. 480 с.

Стругацкий Аркадий, Стругацкий Борис. Полдень, XXII век. Москва: Издательство АСТ, 2016. 352 с.

Стругацкий Аркадий, Стругацкий Борис. Хищные вещи века. Москва: АСТ, 2016. 256 с.

Хаксли Олдос. О дивный новый мир. Москва: Издательство АСТ, 2014. 288 с

Biletskyi Vitaliy. Political agitation and state of mental maturity of the domestic society. Cxid. 2019. № 3 (161). C. 53-56.

Віталій Білецький,

Донеиький національний університет імені Василя Стуса (м. Вінниия, Украӥна)

e-mail: biletsk750@gmail.com, ORCID0000-0003-2818-131X

\section{ДИСКУРС МАНІПУЛЯЦІїСВІДОМІСТЮ У ЛІТЕРАТУРНИХ ТВОРАХ О. ГАКСЛІ, А. ТА Б. СТРУГАЦЬКИХ. АНАЛОГІЇ З СУЧАСНІСТЮ}

У статті автор показує, як літературні твори утопійного та антиутопійного жанру можуть виступати джерелом наукового, зокрема, соціально-філософського аналізу суспільних феноменів. Цікавлячись явищем маніпуляції масовою свідомістю, автор відшуковує серед письменників тих, хто висвітлює ї̈ з яскравою художньою образністю. Наразі розглядається Олдос Гакслі, Аркадій та Борис Стругацькі й їх відповідні твори: «Цей новий світ» («Brave New World»), «Населений острів», «Полудень, XXII сторіччя» та інші. Вказані автори ретельно і комплексно вибудовують динамічну картину суспільних відносин й стану суспільних інститутів як під час громадського спокою, так і в ситуації загарбницької війни. Шляхом застосування ряду наукових методів виявилося, що літератори показали маніпуляцію масовою свідомістю цілком зріло з точки зору соціології, соціальної філософії, релігієзнавства та соціальної психології. Їх принципове бачення інструментального впливу на маси людей тотожне з науковим. Це ж стосується і підходу до демонстрації модифікацій інституту суспільної моралі, релігії, педагогіки та освіти для впливу на населення. Автор робить висновки зокрема щодо подібності сучасного маніпулятивного політичного впливу на громадян України до того, який існує у світі тотального споживання, деградації християнської моралі Олдоса Гакслі. У свою чергу показана Стругацькими мілітаристична обробка населення тотожна пропаганді, яка сьогодні проводиться всередині Російської Федерації. Робиться наголос на тому, що особлива корисність аналізу літературних творів подібного типу полягає у доповненні суто раціональної картини, яку дає знання наукове, а ознайомлення з даними творами цілком може ініціювати відповідні наукові розвідки для відстеження паралелей та аналогій.

Ключові слова: маніпуляція свідомістю; "людина маси"; "Ера T"; "хижі речі століття"; "Полудень"; соціальнофрілософрські погляди; антиутопія; деградація особистості; віра; масова покора.

(C) Vitaliy Biletsky

Надійшла до редакції: 22.01.2020

Прийнята до друку: 07.02.2020

СХІД № 1 (165) січень-лютий 2020 р. 